\title{
Kepatuhan Pengelolaan Penyakit Diabetes mellitus Tipe II melalui Peer Group Support di Wilayah Kerja Puskesmas Kebonsari Surabaya
}

\author{
Yuyun Diantiningsih*, Kusnanto**, Abu Bakar** \\ *Mahasiswa Program Studi Ilmu Keperawatan, Fakultas Keperawatan Universitas Airlangga \\ ** Staf Pengajar Fakultas Keperawatan Universitas Airlangga \\ Email: diedie_yun@yahoo.co.id
}

\begin{abstract}
Introduction: Diabetes Mellitus is a chronic disease that cannot be cured so that compliance is required to manage the disease. Patient compliance is in accordance with the provisions of the behavior of health workers. The aimed of this study was to analyze the effect of peer group support on the compliance of type 2 Diabetes mellitus disease management.Methods: This research was used a quasy experiment pre post test designed. The selection of sample using a purposive sampling and was obtained 16 respondents from 77 population. The independent variable was a peer group support that carried out for two weeks while dependent variable was dietary compliance, exercise and drugs consumption which data was collected by observation sheet. The data were analyzed using Wilcoxon Signed Rank Test and Mann Whitney U Test with significant value of $\alpha \leq 0.05$.Result: The results showed that there was increase of dietary compliance $(p=0.012)$ but there was no effect of peer group support for dietary compliance $(p=0.14)$, the increase of exercise compliance $(p=0.012)$ and there was effect of peer group support for exercise compliance $(p=0.004)$, and the increase of drugs consumption compliance $(p=0.027)$ and there was effect of peer group support for drugs consumption compliance $(p=0.048)$.Discussion: It can be concluded that peer group support had good effect to improve dietary compliance, exercise, and drugs consumption so that blood sugar could be controlled. Larger respondents, more proper instruments and longer duration of study will be needed to get a better result of the further research.
\end{abstract}

Keywords: Peer Group Support, Compliance, Diabetes mellitus

\section{PENDAHULUAN}

$\begin{array}{cccc}\text { American } & \text { Diabetes } & \text { Assosiation } \\ \text { [ADA }] & (2008) & \text { dalam } & \text { PERKENI }\end{array}$ (2011)menyatakan bahwa Diabetes mellitus (DM) tipe 2 merupakan kelompokDM dengan resistensi insulin dan defisiensi insulin relatifserta gejala yang tidak dapat dirasakan pada stadium awal dan tidak terdiagnosis sampai terjadinya komplikasi. Pengelolaan kadar glukosa darah penderita DM tipe2 dengan melaksanakan 4 pilar pengelolaan penyakit DM tipe 2 yaitu pendidikankesehatan (education), diet (rencana makan), latihan fisik (exercise) dan konsumsiobat hipoglikemi. Keberhasilan 4 pilar tersebut dapat diketahui dengan melakukankontrol kesehatan secara rutin khususnya kontrol glukosa darah (Misnadiarly,2006).

Berdasarkan hasil studipendahuluan yang dilakukan oleh peneliti kepada20 orang penderita DM dengan menggunakan kuisioner menyatakan bahwa 17 orang atau $85 \%$ tidak patuh terhadap diet, 10 orang atau $50 \%$ tidak patuh terhadapexercise dan 17 orang atau $85 \%$ tidak patuh dalam mengkonsumsi obat sesuaidengan anjuran tenaga kesehatan. Ketidakpatuhan ini disebabkan oleh beberapafaktor antara lain tidak ada waktu untuk kontrol kesehatan, tidak tahu informasitentang penyakitnya, keadaan ekonomi yang masih rendah dan faktor sosialbudaya. Selama ini usaha yang sudah dilakukan oleh Puskesmas KebonsariSurabaya untuk meningkatkan kepatuhan penderita DM dalam mengatur 
polamakan, exercise dan konsumsi obat adalah konseling individu, paguyupan DMdan penyuluhan yang dilakukan di ruang tunggu Puskesmas Kebonsari. Konselingindividu dan penyuluhan yang dilakukan terhitung tidak efektif untukmeningkatkan pengetahuan penderita karena pemberian informasi yang diberikantidak ada follow up-nya sehingga tidak ada perubahan peningkatan kepatuhan.

$$
\text { Pengelolaan DM tipe } 2
$$

membutuhkan partisipasi aktif dari tenagakesehatan, keluarga dan masyarakat untuk mendampingi penderita dalam upayapeningkatan kepatuhan pengelolaan penyakit DM tipe 2 dengan teratur danterkontrol (Tjokroprawiro, 2011). Support system sangat berperan untuk meningkatkankepatuhan pengelolaan penyakit DM tipe 2 (Friedman, 1998). Hal ini didukungoleh hasil penelitian Ilkafah (2011) tentang pengaruh peer group support terhadapself-efficacy, kontrol glukosa darah dan self care activities pada penderita DMdengan 29 responden menyatakan $45 \%$ atau 19 orang terjadi peningkatan kontrolglukosa darah, yang berarti penderita mengalami peningkatan kemandirian dalampengelolaan penyakitnya.

Peer group support merupakan salah satu supportsystem dari sekelompok orang yang menderita penyakit yang sama. Peer groupsupport dapat mengurangi masalah perilaku kesehatan, mengurangi depresi danmempunyai kontribusi untuk meningkatkan kepatuhan pengelolaan penyakit DMtipe 2. Pengaruh peer group support dalam meningkatkan kepatuhan pengelolaanpenyakit DM tipe 2 masih perlu dibuktikan lagi.

Berdasarkan data yang didapatkan dari balai pengobatan PuskesmasKebonsari Surabaya, tahun 2009 terdapat penderita DM tipe 2 sebanyak 1071,tahun 2010 sebanyak 1572, tahun 2011 sebanyak 1581 dan sampai dengan akhirbulan Februari 2012 didapatkan 349 penderita yang terdiri atas 70 penderita laki-laki dan 279 penderita perempuan. Peningkatan penderita DM tipe2 di wilayah tersebut, dari tahun ke tahun jumlahnya semakin meningkat. Hal inidisebabkan oleh pola hidup yang tidak sehat dan adanya mobilisasi pendudukserta penduduk musiman. Sebanding dengan meningkatnya jumlah penderita DMtipe 2, tingkat kepatuhan pengelolaan DM tipe 2 semakin tidak terkontrol danakan menyebabkan komplikasi (FKUI, 2009). Komplikasi penderita DM tipe 2 yang terjadi di wilayah kerja PuskesmasKebonsari sampai saat ini belum ditemukan tetapi penderita harus tetapmeningkatkan kepatuhan pengelolaan penyakit DM tipe 2 untuk menghindarikemungkinan komplikasi yang akan terjadi.

Tingkat kepatuhan pengelolaan penyakit DM tipe 2 dipengaruhi olehbeberapa faktor yaitu pemahaman tentang instruksi, kualitas interaksi, dukungansosial keluarga atau teman sebaya, serta keyakinan, sikap dan kepribadian pasien(Niven, 2005). Intervensi yang tepat untuk meningkatkan kepatuhan tersebut yaitudengan memberikan informasi dan dukungan khususnya dukungan dari kelompokteman sebaya (peer group support). Menurut Randall (2010) peer group supportmerupakan tempat yang praktis bagi sekelompok orang yaitu penderita DM tipe 2untuk memberikan dan menerima dukungan emosional serta pertukaran informasi.

Kelompok teman sebaya (peer group) dapat memenuhi kebutuhan pribadipenderita DM tipe 2, menghargai, menyediakan informasi, meningkatkan hargadiri dan memberikan identitas bagi penderita DM tipe 2. Penderita akan lebihterbuka mengungkapkan permasalahannya dalam peer group ini. Hasil penelitianyang dilakukan oleh Nuryati (2010) tentang pelaksanaan peer group supportuntuk meningkatkan pengetahuan yang dilakukan 2 kali per minggu selama 2 minggu dengan durasi setiap pertemuan 60 menit menunjukan hasil yang efektifyaitu 100\% pengetahuan penderita meningkat. Ilkafah (2011) juga melakukanpeer group support 2 kali per minggu selama 2 minggu dengan durasi 60 menituntuk meningkatkan kemandirian dalam pengelolaan penyakit DM tipe 2.

Penderita DM tipe 2 yang baru ataupun yang lama dianjurkan untukbergabung dalam kelompok pendukung untuk mendapatkan partisipasi darisesama anggota. Partisipasi seperti ini dapat membantu penderita dalammeningkatkan kepatuhan menjalankan diet (rencana makan), exercise, dankonsumsi obat serta dalam menghadapi perubahan gaya hidup 
yang terjadi padapenderita DM baru dan mengatasi komplikasinya. Penderita DM yang ikut sertadalam peer group support sering mendapatkan berbagai informasi danpengalaman yang berharga dari para penderita lainnya. Kelompok pendukungmemberikan kesempatan untuk berdiskusi berbagai stategi dalam mengatasipenyakit dan pengelolaannya (Smeltzer \& Bare, 2002). Dukungan yang diberikanmelalui partisipasi antar kelompok pendukung dapat membantu penderita untukmeningkatkan kepatuhan menjalankan pilar pengelolaan penyakit DM tipe 2 .

Berdasarkan uraian diatas dapat ditarik kesimpulan bahwa peer groupsupport dapat diterapkan di Puskesmas Kebonsari Surabaya sebagai kontribusidalam mengembangkan ilmu keperawatan khususnya dalam keperawatankomunitas untuk meningkatkan kepatuhan diet, exercise, dan konsumsi obat padapenderita DM tipe 2. Tujuan dari penelitian ini adalah untuk menjelaskan pengaruh peer group support terhadap kepatuhan pengelolaanpenyakit DM tipe 2 di wilayah kerja Puskesmas Kebonsari Surabaya.

\section{BAHAN DAN METODE}

Desain penelitian yang digunakan dalam penelitian ini adalah penelitian eksperimen semu (Quasy-Experiment)dengan pendekatan Non-Equivalen Control Group atau Non-Randomized ControlGroup PretestPostest Design. Besar sampel dalam penelitian ini adalah masing-masing 14 responden baik untuk kelompok perlakuan maupun untuk kelompok kontrol yang ditentukan berdasarkan teknik purposivesampling. Penentuan responden pada kedua kelompok ini selanjutnya ditentukan dengan menggunakan teknikmatching berdasarkan usia, jenis kelamin, dan tingkatpendidikan agar kedua kelompok memiliki distribusi data yang sama.Variabel independen pada penelitian ini adalah peer groupsupport.Variabel dependen dalam penelitian ini adalah kepatuhan pengelolaan DM tipe 2 berupa diet, exercise, dankonsumsi obat.

$$
\text { Pada penelitian ini, peneliti }
$$
mengumpulkan data dari responden dengan meminta responden menjawab pertanyaan secara tertulis dengan mengisi kuesioner penelitian.Kuesioner dalam penelitian ini adalah kuesioner tentang kualitas tidur yaitu Pittsburgh Sleep Quality Index (PSQI) yang berisi close-ended questions.Keuntungan menggunakan PSQI karena memiliki validitas dan reliabilitas yang tinggi, namun metode PSQI ini juga memiliki kekurangan yaitu pengisian kuesioner PSQI dapat memperoleh hasil yang kurang akurat dikarenakan keterbatasan dan kesulitan klien untuk memahami pertanyaan sehingga perlu untuk dipandu dalam pengisian. Kuesioner ini terdiri dari 16 pertanyaan dengannilai validitas 0,840 . Analisis data dalam penelitian ini menggunakan uji statistik Spearman Rho untuk mengetahui hubungan antara variabel independen dan dependen dengan skala data ordinal dan tingkat kemaknaan $\mathrm{p}=0,05$.

\section{HASIL}

Hasil penelitian ini menunjukkan bahwa dengan teknik matching yang dilakukan maka distribusi responden pada kedua kelompok memiliki kesamaan. Distribusi responden berdasarkan jenis kelaminantara kelompok perlakuan dan kelompok kontrol sama yaitu, 1 responden $(12,5 \%)$ laki-laki dan 7 responden $(87,5 \%)$ perempuanuntuk masing-masng kelompok. Distribusi responden berdasarkan usia antarakelompok perlakuan dan kelompok kontrol pun menunjukkan hasil yang samayaitu, 2 orang responden (25\%) berusia 41-50 tahun dan 6 orang responden (75\%)berusia 51-60 tahun untuk masingmasing kelompok.

Distribusi responden berdasarkan tingkat pendidikanresponden pada kelompok perlakuan dan kelompok kontrol menunjukkan hasil yang samayaitu terdapat 3 $(37,5 \%)$ responden tidak lulus Sekolah Dasar, 2 (25\%)responden lulus Sekolah Dasar, dan $3(37,5 \%)$ responden lulus Sekolah MenengahPertama. Distribusi responden berdasarkan lama respondenmenderita penyakit pada kelompok perlakuan terdapat $3 \quad(37,5 \%)$ respondenkurang dari 1 tahun, $1(12,5 \%)$ responden 1-2 tahun, dan 4 (50\%) responden 3-5tahun. Pada kelompok kontrol terdapat 2 (25\%) responden kurang dari 1 tahun, 
$1(12,5 \%)$ responden 1-2 tahun, 2 responden (25\%) 3-5 tahun, dan 3 (37,5\%)responden lebih dari 5 tahun.

Pada tabel 1 dapat dilihat bahwa hasil pre test kelompok perlakuan sebagian besarresponden yaitu 7 (87,5\%) mengalami tingkat kepatuhan kurang. Sebagian besarresponden yaitu $7(87,5 \%)$ setelah intervensi peer group support mengalamipeningkatan kepatuhan cukup dan baik, kecuali responden 1 tetap dengan skalakurang dan responden 6 yang tidak mengalami perubahan kepatuhan. Hasil post test kelompok kontrol menyatakan sebagian besar responden jugamengalami peningkatan prosentase kepatuhan diet meskipun tidak mengubahtingkat kepatuhannya. Hasil pre testdan post test tingkat kepatuhanpada kelompok kontrol dapat dilihat pada tabel 1 . Kelompokkontrol tidak diberikan intervensi peer group support, penderita mendapatkanperlakuan seperti biasa dan media informasi booklet dari peneliti.

Hasil penelitian ini menunjukkan bahwa terdapat perubahan tingkat kepatuhan diet pada kelompok perlakuan sebelum dan sesudah dilakukan intervensi peer group supportyang ditunjukkan dengan hasil analisis statistik menggunakan Wilcoxon Signed Rank Testdiperoleh nilai $\mathrm{p}=0,012$. Pada kelompok kontrol hasil analisis statistik menunjukkan nilai $\mathrm{p}=0,046$ yang berarti terdapat peningkatan kepatuhan diet dengan diberikan intervensi seperti biasa dan media informasi booklet. Hasil uji statistik Mann Whitney $U$ Test diperoleh nilai $\mathrm{p}=0,14$ yang menunjukkan bahwa tidak ada perbedaan yang signifikan antara kelompok perlakuan dan kelompok kontrol, hal ini berarti tidak ada pengaruh intervensi peer group support terhadap peningkatan kepatuhan diet pada penderita DM.

Pada tabel 2 dapat dilihat bahwa hasil pre test pada kelompok perlakuan dalam menjalankan exercise terdapat 8 $(100 \%)$ responden berada pada tingkat kepatuhan kurang. Semua responden (100\%) setelah intervensi peer group support mengalami peningkatan kepatuhan menjadi cukup dan baik, kecuali responden 4 yang tidak mengalami perubahan tingkat kepatuhan tetapi mengalami peningkatan prosentase sebesar 19\%. Peningkatan signifikan dialami oleh responden 3 sebesar $71,4 \%$ sedangkan peningkatan kepatuhan paling rendah dialami oleh responden 7 sebesar $6,1 \%$.

Hasil pre test pada kelompok kontrol terdapat $8(100 \%)$ responden dengan tingkat kepatuhan kurang. Hasil post test didapatkan $6(75 \%)$ responden tetap dengan tingkat kepatuhan kurang dan 2 (25\%) responden mengalami peningkatan kepatuhan menjadi cukup yaitu responden 1 dan responden 8 dengan peningkatan prosentase rendah. Penurunan prosentase kepatuhan signifikan dialami oleh responden 6 sebesar 28,6\%. Kelompok kontrol tidak diberikan intervensi peer group support, penderita mendapatkan perlakuan seperti biasa dan media informasi berupa booklet dari peneliti.

Hasil penelitian ini menunjukkan bahwa terdapat peningkatan kepatuhan exercise DM yang signifikan dengan diberikan intervensi peer group supportyang ditunjukkan dengan hasil analisis statistik menggunakan Wilcoxon Signed Rank Test dimana diperoleh nilai $\mathrm{p}=0,012$. Hasil analisis statistik pada kelompok kontrol diperoleh nilai $\mathrm{p}=0,34$ yang berarti tidak terdapat peningkatan kepatuhan exercise dengan intervensi seperti biasa dan media informasi booklet. Hasil analisis statistik Mann Whitney $U$ Test diperoleh nilai $\mathrm{p}=0,004$ yang menunjukkan terdapat perbedaan yang signifikan antara kelompok perlakuan dan kelompok kontrol yang berarti ada pengaruh intervensi peer group support terhadap peningkatan kepatuhan exercise pada penderita DM.

Tabel 3 menunjukkan hasil pre test konsumsi obat kelompok perlakuan dimana terdapat $2(25 \%)$ responden dengan tingkat kepatuhan kurang, $5(62,5 \%)$ responden dengan tingkat kepatuhan cukup, dan 1 $(12,5 \%)$ responden dengan tingkat kepatuhan baik. Sebagian besar yaitu $6 \quad(75 \%)$ responden setelah intervensi berada pada tingkat kepatuhan baik (responden 1, 3, 4, 5, 6, dan 7). Hasil pre test pada kelompok kontrol terdapat 2 (25\%) responden dengankepatuhan kurang, $3 \quad(37,5 \%)$ reponden dengan kepatuhan cukup, dan 3 $(37,5 \%)$ responden dengan kepatuhan baik. Hasil post test terdapat 3 (37,5\%) respondenmengalami penurunan kepatuhan dan penurunan signifikan terjadi pada responden7 sebesar 57,1\%.

Penelitian ini menunjukkan hasil bahwa terdapat peningkatan kepatuhan 
konsumsi obat DM yang signifikan dengan diberikannya intervensi peer group support, hal ini ditunjukkan dengan hasil analisis statistik menggunakan Wilcoxon Signed Rank Test dengan nilai $\mathrm{p}=0,027$. Pada kelompok kontrol tidak terdapat peningkatan kepatuhan konsumsi obat dengan intervensi seperti biasa dan media informasi booklet.Hasil analisis statistik menggunakan Wilcoxon Signed Rank Test menunjukkan nilai $\mathrm{p}=0,18$.
Hasil analisis statistik Mann Whitney U Test diperoleh nilai $\mathrm{p}=0,048$ yang berarti terdapat perbedaan yang signifikan antara kelompok perlakuan dan kelompok kontrol yang berarti terdapat pengaruh intervensi peer group support terhadap peningkatan kepatuhan konsumsi obat pada penderita DM.

Tabel 1. Hasil Analisis Statistik Tingkat Kepatuhan Diet pada Kelompok Perlakuan dan Kelompok Kontrol Di Wilayah Kerja Puskesmas Kebonsari Surabaya 3 Mei-29 Mei 2012

\begin{tabular}{ccccccc}
\hline \multirow{2}{*}{ No. } & \multicolumn{5}{c}{ Skor Tingkat Kepatuhan Diet(dalam Persen) } \\
\cline { 2 - 7 } & Pre & Post & Selisih & Pre & Post & Selisih \\
\cline { 2 - 7 } & 20,6 & 21,4 & 0,8 & 12,7 & 27 & 14,3 \\
2 & 28,8 & 65,9 & 37,1 & 55,6 & 51,6 & -4 \\
3 & 51,6 & 67,5 & 15,9 & 36,5 & 51,6 & 15,1 \\
4 & 27,8 & 62,7 & 34,9 & 40 & 40 & 0 \\
5 & 43 & 76,2 & 33,2 & 33,3 & 33,3 & 0 \\
6 & 60,3 & 74,6 & 14,3 & 35 & 42 & 7 \\
7 & 42,9 & 64,8 & 21,9 & 63,5 & 72 & 8,5 \\
8 & 26,2 & 80 & 53,8 & 75,4 & 94 & 18,6 \\
\hline Mean & 37,65 & 64,14 & 44,00 & 51,44 \\
\hline SD & 13,94 & 18,32 & 19,81 & 21,96 \\
\hline \multicolumn{5}{c}{ Wilcoxon Signed Rank Test } \\
\hline \multicolumn{7}{c}{ Wilcoxon Signed Rank Test } \\
\hline \multicolumn{7}{c}{$(\mathrm{p}=0,012)$}
\end{tabular}

Mann Whitney U Test

$(\mathrm{p}=0,14)$

Keterangan:

$\begin{aligned} \text { Mean } & =\text { rerata } \\ \mathrm{SD} & =\text { Standar Deviasi } \\ \mathrm{p} & =\text { derajat kemaknaan }\end{aligned}$
Skor tingkat kepatuhan diet $\leq 55 \%$ : kurang patuh

$56 \%-75 \%$ : cukup patuh $\geq 76 \%$ : baik

Tabel 2. Hasil Analisis Statistik Tingkat Kepatuhan Exercise pada Kelompok Perlakuan dan Kelompok Kontrol Di Wilayah Kerja Puskesmas Kebonsari Surabaya 3 Mei-29 Mei 2012

\begin{tabular}{|c|c|c|c|c|c|c|}
\hline \multirow{3}{*}{ No. } & \multicolumn{6}{|c|}{ Skor Tingkat Kepatuhan Exercise(dalam Persen) } \\
\hline & \multicolumn{3}{|c|}{ Perlakuan } & \multicolumn{3}{|c|}{ Kontrol } \\
\hline & Pre & Post & Selisih & Pre & Post & Selisih \\
\hline 1 & 42,9 & 66,7 & 23,8 & 52,4 & 57,1 & 4,7 \\
\hline 2 & 14,3 & 76,2 & 61,9 & 52,4 & 52,4 & 0 \\
\hline 3 & 14,3 & 85,7 & 71,4 & 42,9 & 47,6 & 4,8 \\
\hline 4 & 28,6 & 47,6 & 19 & 42,9 & 42,9 & 0 \\
\hline 5 & 14,3 & 71,4 & 57,1 & 28,6 & 42,9 & 1,3 \\
\hline 6 & 42,9 & 76 & 33,1 & 42,9 & 14,3 & $-28,6$ \\
\hline 7 & 42,9 & 57,1 & 6,1 & 28,6 & 38,1 & 9,5 \\
\hline 8 & 28,6 & 66,7 & 38,1 & 42,9 & 57,1 & 14,2 \\
\hline Mean & 29,79 & 68,43 & & 41,70 & 44,05 & \\
\hline \multirow[t]{2}{*}{ SD } & 12,15 & 11,91 & & 9,09 & 13,87 & \\
\hline & \multicolumn{3}{|c|}{$\begin{array}{l}\text { Wilcoxon Signed Rank Test } \\
(\mathrm{p}=0,012)\end{array}$} & \multicolumn{3}{|c|}{$\begin{array}{l}\text { Wilcoxon Signed Rank Test } \\
\qquad(\mathrm{p}=0,34)\end{array}$} \\
\hline
\end{tabular}

Keterangan:

Mean $=$ rerata

$\mathrm{SD}=$ Standar Deviasi 
$\mathrm{p} \quad=$ derajat kemaknaan

Skor tingkat kepatuhan diet

$$
\begin{array}{ll}
\leq 55 \% & : \text { kurang patuh } \\
56 \%-75 \% & : \text { cukup patuh } \\
\geq 76 \% & : \text { baik }
\end{array}
$$

Tabel 3. Hasil Analisis Statistik Tingkat Kepatuhan Konsumsi Obat pada Kelompok Perlakuan

\begin{tabular}{|c|c|c|c|c|c|c|}
\hline \multirow{3}{*}{ No. } & \multicolumn{6}{|c|}{$\begin{array}{c}\text { Skor Tingkat Kepatuhan Konsumsi Obat } \\
\text { (dalam Persen) }\end{array}$} \\
\hline & \multicolumn{3}{|c|}{ Perlakuan } & \multicolumn{3}{|c|}{ Kontrol } \\
\hline & Pre & Post & Selisih & Pre & Post & Selisih \\
\hline 1 & 100 & 100 & 0 & 100 & 64,3 & $-35,7$ \\
\hline 2 & 0 & 0 & 0 & 75 & 50 & -25 \\
\hline 3 & 35,7 & 100 & 64,3 & 57,1 & 71,4 & 14,3 \\
\hline 4 & 67,9 & 100 & 32,1 & 60,7 & 71,4 & 10,7 \\
\hline 5 & 57,1 & 100 & 42,9 & 32,1 & 39.3 & 7,2 \\
\hline 6 & 57,1 & 100 & 42,9 & 39,3 & 14,3 & 25 \\
\hline 7 & 67,9 & 100 & 32,1 & 57,1 & 0 & $-57,1$ \\
\hline 8 & 60,7 & 64,3 & 3,6 & 100 & 100 & 0 \\
\hline Mean & 56,05 & 83,04 & & 65,16 & 51,34 & \\
\hline \multirow[t]{3}{*}{ SD } & 28,57 & 35,80 & & 25,17 & 32,72 & \\
\hline & \multicolumn{3}{|c|}{$\begin{array}{l}\text { Wilcoxon Signed Rank Test } \\
(\mathrm{p}=0,027)\end{array}$} & \multicolumn{3}{|c|}{$\begin{array}{l}\text { Wilcoxon Signed Rank Test } \\
\qquad(\mathrm{p}=0,18)\end{array}$} \\
\hline & & & $\overline{M a n n ~} \mathrm{~V}$ & $\begin{array}{l}\text { y } U T e \\
8)\end{array}$ & & \\
\hline
\end{tabular}
dan Kelompok Kontrol Di Wilayah Kerja Puskesmas Kebonsari Surabaya 3 Mei-29 Mei 2012

Keterangan:

$$
\begin{aligned}
& \text { Mean }=\text { rerata } \\
& \mathrm{SD}=\text { Standar Deviasi } \\
& \mathrm{p}=\text { derajat kemaknaan }
\end{aligned}
$$

\section{PEMBAHASAN}

Mayoritas responden sebelum diberi intervensi peer group support padakelompok perlakuan, mempunyai kepatuhan diet yang kurang. Hal ini sesuaidengan teori perubahan perilaku yang menyatakan bahwa terbentuknya tindakan(kepatuhan diet) seseorang dipengaruhi oleh pengetahuan atau kognitif(Notoatmodjo, 2007). Sulitnya prosedur pelaksanaan diet serta didukung olehbelum maksimalnya informasi diet dari pihak puskesmas menyebabkan respondenbelum menjalankan diet dengan benar. Kurangnya dukungan (teman sebaya) yangbersedia mendengarkan keluhan dan membantu pemecahan masalah dalammenjalankan diet menjadi penyebab utama rendahnya kepatuhan terhadap diet.Hal ini sesuai dengan pernyataan Smet (1994) bahwa strategi untuk meningkatkankepatuhan antara lain adalah adanya dukungan profesional kesehatan, dukungansosial, perilaku kesehatan, dan
Skor tingkat kepatuhan diet

$\begin{array}{ll}\leq 55 \% & : \text { kurang patuh } \\ 56 \%-75 \% & : \text { cukup patuh } \\ >76 \% & : \text { baik }\end{array}$

$\geq 76 \%$ : baik pemberian informasi. Rendahnya persepsi dan selfefficacy responden tentang manfaat diet juga menyebabkan responden engganuntuk mengatur pola makannya.

Peningkatan kepatuhan diet terjadi setelah diberikan intervensi peer groupsupport sehingga mayoritas responden memiliki kepatuhan cukup dan baik. Hasilobservasi peneliti, dengan melihat buku catatan menunjukkan bahwa sebagianbesar responden setelah intervensi mampu melakukan pengaturan pola makandengan benar. Sehari tiga kali makan besar (pagi, siang, dan sore) serta tiga kalimakan kecil yang dilakukan disela-sela jam makan besar atau selang waktu tigajam setelah makan besar dengan memperhatikan prinsip 3J yaitu tepat jumlah,tepat jenis, dan tepat jam. Tepat dalam hal jumlah menunjukkan peningkatanpaling rendah diantara tepat jenis dan jam. Hal ini disebabkan oleh faktorkebiasaan belum berhenti makan sebelum kenyang yang dilakukan oleh sebagianbesar responden. 
Terdapat satu responden yang tidak mengalami peningkatan kepatuhandiet setelah dilakukan intervensi peer group support. Menurut responden, hal inidisebabkan karena sulitnya prosedur pengaturan pola makan. Berdasarkanpengamatan peneliti, responden tersebut memang mengikuti peer group supportsecara teratur, namun kadang kurang memperhatikan dan menyelami informasidengan baik serta dimungkinkan juga responden tidak menyimpan informasidalam ingatan. Berdasarkan pengamatan tersebut, peneliti menilai bahwa kualitaslebih penting daripada kuantitas dalam mengikuti peer group support. Kuantitaspeer group support dengan didukung oleh kualitas yang maksimal akanmenghasilkan efek yang baik.

Hasil analisis data tentang pengaruh peer group support terhadapkepatuhan diet pada kelompok perlakuan menunjukkan adanya pengaruh yangsignifikan. Sesuai dengan penelitian sebelumnya oleh Ilkafah (2011) yangmenyatakan bahwa peer group support dapat meningkatkan self efficacypengelolaan DM. Self efficacy yang tinggi akan meningkatkan self care activitiessehingga kepatuhan penderita dalam menjalankan pilar pengelolaan DM salahsatunya diet juga akan meningkat. Hasil tersebut didukung oleh teori belajar sosialBandura (1997) yang menyatakan bahwa seseorang bertindak harus ada motivasidan dorongan dari lingkungan. Motivasi dalam penelitian ini berasal dari temansebaya dengan penyakit yang sama.

Menurut peneliti, perubahan kepatuhan diet pada kelompok perlakuan terjadi karena: pertama, adanya dukungan berupa informasi diet dan motivasiteman sebaya dalam pemecahan masalah diet sehingga responden dapatmenjalankan prosedur diet sesuai informasi yang diperoleh. Robert Weiss (1974)dalam Peplau (2002) menyatakan bahwa hubungan sosial berupa dukungan dapatmemberikan kesempatan bagi individu untuk menikmati berbagai kebersamaan.Kebersamaan dalam berbagai kegiatan, minat dan sikap mematuhi aturan dietdiberikan oleh hubungan dalam kelompok teman sebaya.

Kedua, penderita merasa mempunyai kelompok sosial baru yang siapmendengarkan keluhan dan berbagi strategi pemecahan masalah diet sertamembantu meningkatkan kepatuhan dalam menjalankan diet. Hal tersebut terlihatsaat tahap presentasi masalah, responden dengan no. kode 1 mengungkapkan tidakbisa tarak makanan, yang artinya tidak bisa menjalankan diet dengan benar.Responden tersebut menyatakan selalu ingin makan saat melihat makananmeskipun sudah merasa kenyang. Hal ini sesuai dengan gelaja akut DM yaitubanyak makan, banyak minum, dan banyak kencing (Tjokroprawiro, 2011).Masalah tersebut mendapatkan strategi pemecahan masalah dari respondendengan no. kode 8 berupa meminum banyak air mineral saat timbul rasa inginmakan. Responden dengan no. kode 8 juga memberikan strategi pemecahanmasalah yang diungkapkan oleh responden dengan no. kode 3. Responden denganno. kode 3 merupakan tokoh masyarakat yang sering diundang saat acarapernikahan, syukuran dan lainnya, dimana setiap acara disediakan makanan yangharus dimakan untuk menghargai tuan rumah. Responden tersebut tidak bisamengontrol jenis, jam serta jumlah makanan dan mendapatkan strategi pemecahanmasalah berupa jangan mengambil makanan yang berisiko untuk meningkatkanglukosa darah dengan cepat seperti sirup, anggur, cake dan lainnya.

Ketiga, meningkatnya persepsi dan self efficacy tentang manfaat mematuhidiet akan membawa perbaikan pada kondisi kesehatan karena akan menstabilkanglukosa darah serta dapat mencegah komplikasi. Diet merupakan pilar utamapengendali glukosa darah pada penderita DM (Misnadiarly, 2006). Peningkatanpersepsi diri terhadap pengelolaan glukosa darah dengan menjalankan diet akanmenstimulus keyakinan penderita untuk hidup sehat (Greco et al. 2001).

Keempat,adanya fasilitas penunjang booklet yang memudahkan penderita untuk menyusunmakanan yang harus dimakan karena didalamnya terdapat berbagai aturan, jammakan, jumlah makanan, jenis makanan berserta kandungan kalorinya danmakanan pengganti sehingga penderita dapat dengan mudah untuk melakukanperencanaan makan. Didukung pernyataan Kuerstein (1986) dalam Niven (2005)yang menyatakan bahwa penggunaan media informasi secara mandiri, 
berupabuku (booklet) dan kaset dapat meningkatkan tindakan kepatuhan.

Menurut peneliti, peningkatan kepatuhan diet juga disebabkan oleh faktorusia, tingkat pendidikan, dan lamanya menderita penyakit. Seluruh respondenpada kelompok perlakuan berada pada usia 40-60 tahun dimana usia tersebutmulai menunjukkan adanya penurunan fungsi fisiologis sehingga kemampuanpenyerapan informasi juga menurun (Notoatmodjo, 2007). Hal ini menyebabkansulitnya responden memahami informasi yang diberikan saat pertemuan peergroup support. Besarnya kemauan responden untuk memahami informasi dandidukung dengan penyampaian informasi oleh peneliti secara berulang-ulang,menyebabkan responden memahami informasi yang diberikan danmengaplikasikannya.

Tingkat pendidikan responden yang mayoritas tidak lulus SD dan SMPmempengaruhi proses belajar. Tingkat pendidikan berpengaruh pada saatpenderita memperoleh pengalaman dari berbagai latihan maupun tugas. Berbekalpengalaman dalam belajar penderita akan cepat tanggap terhadap intervensi yangdatang dan berusaha menyelesaikan masalah dengan cara adaptif. Notoatmodjo(2007) menyatakan semakin tinggi pendidikan seseorang makin mudah orangtersebut menerima informasi. Hal ini sejalan dengan hasil penelitian datademografi mengenai tingkat pendidikan. Perubahan tingkat kepatuhan diet palingsignifikan ditunjukkan oleh responden dengan tingkat pendidikan terakhir adalahSekolah Menengah Pertama.

Penderita yang telah lama menderita penyakit DM kemungkinan memilikikemampuan adaptasi yang lebih baik dalam menjalankan diet daripada penderitayang baru terdiagnosa DM (Gitawati, 2007). Terbukti pada responden dengan no.kode 8 yang menderita DM lebih dari 5 tahun mengalami peningkatan kepatuhandiet paling signifikan. Lamanya seseorang menderita DM tidak selalu berbandinglurus dengan tingkat pengetahuannya. Keadaan lingkungan yang mendukung yaitubanyaknya penderita DM pada tempat tersebut menyebabkan penderita tidaksendiri dalam menghadapi penyakitnya. Semangat penderita untuk hidup sehatjuga mempengaruhi kemamuan penderita untuk menggali informasi lebih dalamdan mengaplikasikannya. Hal ini didukung oleh Notoatmodjo (2007) yangmenyatakan faktorfaktor yang mempengaruhi tingkat penyerapan informasiseseorang antara lain pendidikan, pengalaman, usia, lingkungan dan pekerjaan.

Hal senada ditunjukkan oleh responden pada kelompok kontrol. Hasilstatistik kepatuhan diet pada kelompok kontrol menunjukkan terjadi peningkatankepatuhan diet meskipun kelompok kontrol tidak mendapatkan intervensi peergroup support. Kelompok kontrol mendapatkan intervensi seperti biasa daripuskesmas induk berupa konseling diet serta pemberian media informasi bookletoleh peneliti yang bisa meningkatkan pengetahuan responden tentang pengaturanpola makan. Konseling diet yang diberikan puskesmas induk belum maksimalhanya sebatas makanan yang boleh dikonsumsi dan tidak boleh dikonsumsi tetapimedia informasi booklet mencantumkan berbagai aturan diet secara lengkapberdasarkan prinsip 3J, sehingga kedua media informasi tersebut bisa salingmendukung. Penggunaan media informasi secara mandiri berupa buku (booklet)dan kaset dapat meningkatkan tindakan kepatuhan (Niven, 2005). Pertanyaan yang dilontarkan responden saat peneliti melakukan evaluasi 3 harisekali menyebabkan responden mengetahui apa yang sebelumnya tidakdiketahuinya. Hal ini menyebabkan tanpa intervensi peer group support sebagianbesar responden pada kelompok kontrol dapat meningkatkan kepatuhan dalammenjalankan diet.

Terdapat semua responden pada kelompok perlakuan sebelum diberiintervensi peer group support mempunyai kepatuhan exercise yang kurang.Sebagian besar responden memang sudah melakukan exercise sebelum adanyaintervensi, tetapi exercise yang dilakukan tidak sesuai dengan standart yang telahditentukan. Responden tidak menghitung denyut nadi sebelum exercise, tidakmelakukan pemanasan dan pendinginan, serta tidak melakukan peregangansetelah exercise inti. Masih rendahnya kepatuhan dalam menjalankan exercise DM, dipengaruhi oleh kompleksnya prosedur exercise yang merupakan salah satupilar pengelolaan DM (Heisler, 2007). Penderita DM harus mengikuti 
berbagaiaturan baru dalam menjalankan exercise yang dianggap sulit oleh sebagian besarresponden. Menurut peneliti, rendahnya kepatuhan exercise pada kelompokperlakuan disebabkan karena 1) ketidaktahuan responden tentang informasiprinsip exercise DM yang benar, meliputi: frekuensi, lama, jenis, aktifitas yangdilakukan sebelum, selama dan sesudah exercise inti, dan 2) Kurangnya keinginanresponden untuk mencari informasi exercise DM yang benar sehingga exerciseyang dilakukan hanya sebatas menggerakkan anggota tubuh saja.

$$
\text { Mayoritas responden setelah }
$$

dilakukan intervensi peer group support dapatmelakukan exercise dengan benar sehingga mengalami peningkatan kepatuhanmenjadi skala cukup dan baik. Responden melakukan pemanasan, pendinginan,dan peregangan selama kurang lebih 10 menit sesuai prinsip exercise DM.Tindakan menghitung denyut nadi sebelum exercise tidak pernah dilakukanresponden karena dirasa sangat sulit. Responden kurang terampil dalammenentukan intensitas latihan yang harus dilakukan berdasarkan MHR dan THR.

Terdapat satu responden yang tidak mengalami perubahan kepatuhanexercise setelah intervensi peer group support, yaitu responden dengan no. kode4. Responden tersebut bekerja sebagai penjual jamu. Responden tersebutberpendapat bahwa asalkan badan kita gerak, hal itu sudah termasuk exercise,tanpa harus melakukannya sesuai prinsip exercise DM. Hal ini memang benarbahwa menggerakkan anggota tubuh sudah termasuk olahraga, tetapi perlu dikajiulang tentang gerak yang dilakukan seperti apa. Gerakan yang berlebihan atauhanya bertumpu pada satu anggota badan seperti menumbuk jamu justrumembawa resiko bagi penderita DM seperti cidera muskuloskleletal (Barnes,2012). Exercise yang dipilih pada penderita DM sebaiknya exercise yang dapatmenggerakkan seluruh anggota badan seperti jogging, bersepeda dan berenang.Exercise yang disenangi juga mungkin untuk dilakukan oleh penderita, disampingdapat meningkatkan kesehatan juga dapat meningkatkan kebugaran (Tandra,2008).

Hasil analisis data menunjukkan pada kelompok perlakuan terjadipeningkatan kepatuhan exercise yang signifikan setelah intervensi peer groupsupport. Keberhasilan dari peer group support berkaitan dengan adanya rasakebersamaan dan berbagi pengalaman hidup dengan sesama penderita. PenderitaDM dapat merasakan kebersamaan dengan orang-orang yang memiliki kondisiyang sama dengan dirinya dan mengetahui pemecahan masalah dari masalahexercise yang dialami dengan adanya peer group support, sehingga kepatuhanexercise dapat meningkat.

Hal di atas sesuai dengan hasil penelitian Heisler (2007) yang menyatakandukungan teman sebaya dapat mengurangi masalah perilaku kesehatan termasukperilaku yang berhubungan dengan meningkatkan kepatuhan terhadappengobatan, diet, exercise, dan monitor glukosa darah. Didukung oleh penelitianGail et al.(2010) yang menyatakan bahwa intervensi peer group support dapatmenurunkan depresi, meningkatkan aspek psikososial meliputi kualitas hidup danself efficacy. Kepatuhan exercise merupakan kualitas hidup yang dapat menunjangkestabilan glukosa darah penderita DM. Hasil penelitian Heisler et al.(2010) lainnyayang membandingkan peer group support dengan Nurse Care Management $(\mathrm{NCM})$ untuk mengukur perubahan kadar HbA1C pada penderita DM,menyatakan bahwa peer group support dapat menurunkan HbA1C sedangkanNCM justru meningkatkan HbA1C. Hal ini menunjukan bahwa peer groupsupport lebih efektif daripada NCM dalam meningkatkan kepatuhan menjalankanpilar pengelolaan DM salah satunya exercise.

Persahabatan yang dibentuk dalam kelompok dapat meningkatkansemangat responden dalam menjalankan exercise. Hal ini ditunjukkan saat tahappresentasi masalah, pelaksanaan exercise menjadi salah satu masalah yangdipresentasikan oleh responden dengan no. kode 1. Responden tersebut sulitmelakukan exercise karena sebelumnya tidak pernah atau jarang berolahraga.Masalah exercise tersebut mendapatkan strategi pemecahan masalah olehresponden dengan no. kode 6 berupa olahraga bersama setiap 2 hari sekali di pagihari dengan anggota satu kelompok sehingga termotivasi untuk melakukanexercise. Responden dengan no. kode 8 juga memberikan strategi pemecahanmasalah exercise berupa 
melakukan exercise secara bertahap, perlahan dansetelah merasa tidak berat bisa ditingkatkan baik intensitas maupun durasinya.

Misalnya pagi hari dilakukan olahraga selama 15 menit dan 15 menit lagidilakukan pada sore hari. Solusi tersebut didapatkan responden dengan no. kode 8dari informasi yang tersedia pada booklet.Cepatnya penyerapan informasi yang diberikan pada kelompok perlakuan,dibuktikan dengan munculnya strategi pemecahan masalah yang bermanfaat bagianggota lain. Hal ini dipengaruhi oleh tingkat pendidikan dan berapa lamaresponden menderita penyakit. Semakin tinggi tingkat pendidikan seseorangsemakin cepat orang tersebut menyerap informasi (Notoatmodjo, 2007). Begitujuga semakin lama seseorang menderita penyakit, semakin baik pula kemampuanadaptasi orang tersebut dalam menjalankan terapi pengelolaan penyakit (Gitawati,2007).

Menurut peneliti, perubahan kepatuhan exercise terjadi karena pertamaadanya persepsi dan keyakinan bahwa dengan berolahraga tubuh menjadi lebihsehat. Pada saat berolahraga, resistensi insulin berkurang, sebaliknya sensitivitasinsulin meningkat. Hal ini menyebabkan kebutuhan insulin pada penderita DMsaat berolahraga akan berkurang (Ilyas, 2009). Kedua, adanya dukungan temansebaya yang mengusulkan untuk melakukan exercise bersama setiap 2 hari sekalipada pagi hari. Dukungan yang diberikan menyebabkan responden dapatmelakukan tindakan exercise sesuai prinsipnya. Hal ini didukung oleh teori belajarsosial Bandura (1997) yang menyatakan perlunya motivasi dan dukunganlingkungan untuk bertindak sesuai informasi yang diperoleh. Tersedianya fasilitasbooklet yang memberikan informasi exercise sesuai dengan frekuensi, intensitas,time, dan tipe juga menunjang peningkatan kepatuhan exercise respondenkelompok perlakuan. Responden dapat memperoleh informasi exercise setiap saatdari media booklet tanpa harus bertatap muka dengan peneliti saat intervensiberlangsung. Hal ini menyebabkan cepatnya responden mengaplikasikaninformasi yang diperoleh. Didukung pernyataan Kuerstein (1986) dalam Niven(2005) bahwa penggunaan media informasi secara mandiri, berupa buku (booklet)dan kaset dapat meningkatkan tindakan kepatuhan.

Hal berbeda ditunjukkan responden kelompok kontrol. Hasil post testmenunjukkan mayoritas responden tetap dalam keadaan skala kurang bahkan adayang mengalami penurunan kepatuhan. Niven (2005) menyatakan bahwa tidakada seseorang yang dapat mematuhi instruksi yang diberikan jika orang tersebutsalah memahami instruksi yang diberikan kepadanya. Pemberian media informasibooklet tanpa didukung penjelasan atau pemberian instruksi yang jelas,menyebabkan responden tidak maksimal dalam memperoleh informasi. Hal inimenyebabkan rendahnya perubahan tindakan kepatuhan exercise yangditunjukkan oleh responden kelompok kontrol. Menurut peneliti, kurangnyakesadaran dan keyakinan responden akan pentingnya manfaat exercise jugamenjadi alasan tidak stabilnya kepatuhan exercise yang dilakukan. Sesuai denganBecker (1979) dalam Niven (2005) yang telah membuat suatu usulan bahwamodel keyakinan kesehatan berguna untuk memperkirakan adanyaketidakpatuhan. Kepatuhan konsumsi obat pada kelompok perlakuan sebelum adanyaintervensi sangat bervariasi yaitu kurang, cukup dan baik. Setengah dari jumlahresponden tersebut berada pada skala kurang. Observasi peneliti sebelumdilakukan peer group support didapatkan hasil bahwa sebagian besar respondentidak mengkonsumsi obat tepat waktu dan tepat dosis tetapi tepat dalam hal jenis.Hal ini disebabkan apabila responden sudah merasa tubuhnya dalam keadaanbaik-baik saja, mereka akan mengurangi sendiri dosis obat hingga akhirnya tidakmengkonsumsi obat lagi. Faktor kebosanan karena konsumsi obat DM dilakukanterus menerus, juga menjadi penyebab ketidakpatuhan konsumsi obat responden.

Notoatmodjo (2007) menyatakan bahwa seseorang akan melaksanakan ataumempraktekkan apa yang diketahui setelah seseorang mengetahui stimulus atauobjek, dan mengadakan penilaian atau pendapat terhadap apa yang diketahui.Proses selanjutnya setelah penilaian inilah yang disebut praktek kesehatan, ataudapat 
dikatakan perilaku kesehatan yaitu patuh mengkonsumsi obat.

Responden yang sebelumnya dengan skala kepatuhan kurang dan cukupsetelah dilakukan intervensi peer group support sebagian besar menjadi skala baikdengan nilai atau prosentase maksimal. Sesuai hasil penelitian Heisler (2007)yang menyatakan peer group support dapat mengurangi masalah perilakukesehatan dengan melakukan self management yang efekif. Ketidakpatuhan dalammengkonsumsi obat merupakan salah satu masalah kesehatan. Pengambilan obatyang diresepkan serta mengkonsumsinya sesuai instruksi yang diberikan,diperlihatkan responden dalam penelitian tersebut sehingga glukosa darah dapatterkontrol. Hal ini senada dengan penelitian Norris, Engelgau\&Narayan(2001) yang menyatakanbahwa penderita yang menerima intervensi pendidikan serta melibatkan peranpenderita lain berupa dukungan sosial menimbulkan manajemen DM yang lebihbaik. Manajemen DM tersebut merupakan perubahan perilaku, termasuk perilakukepatuhan konsumsi obat.

Menurut peneliti, peningkatan kepatuhan konsumsi obat pada kelompokperlakuan disebabkan karena responden telah mendapatkan instruksi konsumsiobat yang jelas dari peneliti. Pemberian informasi tentang manfaat konsumsi obatserta akibat yang ditimbulkan saat tubuh tidak mengkonsumsi obat, menyebabkanresponden takut. Rasa bosan karena konsumsi obat DM dilakukan seumur hidup,yang awalnya diungkapkan responden sebelum intervensi peer group support,setelah intervensi rasa tersebut menghilang dan responden bersemangat untukmengkonsumsi obat sesuai aturan. Derajat ketidakpatuhan bervariasi sesuaidengan apakah pengobatan tersebut kuratif, prefentif, jangka panjang atau jangkapendek. Sackett \& Snow dalam Niven (2005) menyatakan kegagalan untukmengikuti program pengobatan jangka panjang, yang bukan dalam kondisi akut,dimana derajat kepatuhannya rata-rata $50 \%$ dan derajat tersebut bertambah buruksesuai waktu.

Sebagian besar responden menyadari bahwa obat tidak hanya dikonsumsisaat tubuh membutuhkan saja, tetapi harus teratur untuk mendapatkan hasil yangmaksimal.
Konsumsi obat harus dilakukan dengan tepat meliputi tepat waktupemasukan, tepat jenis obat, tepat dosis dan apakah responden mengkonsumsiobat lain selain yang diresepkan oleh tenaga kesehatan (Niven, 2005). Terdapatsatu responden pada kelompok perlakuan yang tetap dengan skala kurang bahkantidak mengalami peningkatan prosentase kepatuhan konsumsi obat. Hal inidisebabkan responden tersebut ingin menstabilkan glukosa darah denganmengatur pola makan dan exercise saja.

Pengaturan pola makan dapat mengurangibeban kerja kelenjar pankreas dalam memproduksi hormon insulin, sedangkanaktivitas fisik serta olahraga aerobik yang tepat dapat membantu meningkatkankepekaan reseptor insulin pada sel-sel tubuh (Annisa, 2009). Hal ini menyebabkanpenderita DM dapat hidup dengan penyakitnya tanpa harus menggunakan obathipoglikemi oral atau insulin dengan dosis berlebihan. Soegondo, Soewondo \&Subekti (2009) jugamenyatakan bahwa konsumsi obat dilakukan penderita bila diperlukan saja.Pengendalian glukosa darah sebagian besar dipengaruhi oleh perencanaan makandan aktifitas fisik.

Hasil berbeda ditunjukkan oleh responden pada kelompok kontrol dalammenjalankan konsumsi obat yaitu terdapat tiga responden yang mengalamipenurunan kepatuhan. Seseorang tidak dapat mematuhi instruksi yang diberikan,jika orang tersebut salah memahami instruksinya (Niven, 2005). Pemberian mediainformasi booklet pada responden kelompok kontrol, tanpa didukung penjelasanatau pemberian instruksi yang jelas, menyebabkan responden tidak maksimaldalam memperoleh informasi, sehingga enggan untuk mengaplikasikannya.Sebagian besar responden menyatakan mengkonsumsi obat saat tubuh merasakankeluhan seperti pusing, mual, ataupun muntah. Responden yang dalam keadaanbaik-baik saja memilih untuk tidak mengkonsumsi obat yang dianjurkan olehtenaga kesehatan. Kurangnya kemauan responden untuk mendapatkan informasitentang manfaat obat dan akibat yang ditimbulkan apabila tidak mengkonsumsiobat menjadi alasan utama penurunan kepatuhan konsumsi obat pada 3 respondenkelompok kontrol. 
Menurut peneliti, tingkat pendidikan berpengaruh pada saat penderitamemperoleh pengalaman dari berbagai latihan maupun tugas. Notoatmodjo (2007)menyatakan semakin tinggi pendidikan seseorang makin mudah orang tersebutmenerima informasi. Hal ini sejalan dengan hasil penelitian mengenai tingkatpendidikan responden pada kelompok kontrol. Ketiga responden yang mengalamipenurunan kepatuhan konsumsi obat tidak lulus Sekolah Dasar. Hal inimenyebabkan lamanya penyerapan informasi yang diberikan oleh pihak lain.Pada penelitian ini, pembagian responden pada kelompok perlakuan dankelompok kontrol berdasarkan wilayah (sesuai prosedur pengumpulan data).Perbedaan wilayah antara responden kelompok perlakuan dan respondenkelompok kontrol dilakukan peneliti untuk menghindari kemungkinan bias yangakan terjadi. Berbedanya wilayah tersebut, memungkinkan responden pada keduakelompok tidak akan bertemu karena jaraknya yang cukup jauh. Bahkan saatpeneliti menceritakan kepada beberapa responden kelompok kontrol bahwa diwilayah Pagesangan juga diadakan kunjungan atau penelitian yang sama, sertamenceritakan sedikit informasi data demografi responden kelompok perlakuan,responden kelompok kontrol tidak mengenal semua responden yang ada padakelompok perlakuan. Hal ini mendukung kemungkinan bahwa tidak akan terjadipertukaran informasi antara responden kelompok kontrol dan respondenkelompok perlakuan karena mereka tidak saling mengenal.

Hal ini tidak sepenuhnya bisa mencegah kemungkinan bias yang akanterjadi. Anggota keluarga (istri, suami, anak, saudara) responden bisa sajamengenal responden atau anggota keluarga responden kelompok lain sehinggamenyebabkan pertukaran informasi mengenai pilar pengelolaan DM.Kemungkinan pertukaran informasi antar kelompok tidak terkontrol oleh penelitidan dijadikan sebagai keterbatasn peneliti dalam penelitian ini. Faktor pemberianinformasi dengan kesamaan materi yang disajikan dalam media booklet, yangdiberikan oleh peneliti pada kedua kelompok, menjadi penyebab utamakemungkinan bias yang akan terjadi. Seharusnya, pemberian media informasibooklet pada kelompok kontrol diberikan setelah dilakukan post test. Solusi yangditerapkan peneliti untuk mengurangi bias tersebut adalah responden kelompokkontrol tidak diberi penjelasan mengenai isi booklet sedangkan respondenkelompok perlakuan diberi penjelasan yang mendalam mengenai isi booklet saatintervensi peer group support berlangsung.

Responden pada kelompok perlakuan dan kelompok kontrol, dilakukanpengukuran kadar glukosa darah sebelum, selama dan sesudah intervensi.Pengukuran kadar glukosa darah tidak dikaji oleh peneliti karena hanya dilakukansebagai daya tarik dalam penelitian. Distribusi kadar glukosa darah dalampenelitian ini dapat dilihat pada lampiran 23. Terdapat 3 responden padakelompok perlakuan mengalami penurunan glukosa darah setelah dilakukanintervensi peer group support. Salah satu responden tersebut adalah respondendengan no. kode 3 yang merupakan responden dengan peningkatan kepatuhandiet, exercise, dan konsumsi obat paling signifikan. Seseorang yang menjalankankerangka utama pengelolaan DM, yang meliputi 4 pilar yaitu pendidikankesehatan (education), diet, latihan fisik (exercise), serta terapi farmakologi dapatmemperbaiki kelainan metabolik (Misnadiarly, 2006). Hal tersebut dapat menjagaagar kadar glukosa darah berada dalam batasan normal dan mencegah ataumeminimalkan kemungkinan terjadinya komplikasi DM (PERKENI, 2011).

Hasil penelitian menunjukkan bahwa sebagian besar responden padakelompok perlakuan mengalami peningkatan kepatuhan diet, exercise, dankonsumsi obat. Saat dilakukan pengukuran glukosa darah, hanya terdapat 3responden yang mengalami penurunan, sedangkan responden lainnya mengalamipeningkatan atau tetap. Seharusnya dengan intervensi peer group support,responden mengalami penurunan glukosa darah dan tidak ada yang mengalamipeningkatan glukosa darah. Hal ini sesuai dengan terbuktinya hipotesis penelitianIlkafah (2011) yang menyatakan bahwa peer group support bisa mengontrolglukosa darah penderita DM. Penelitian Greco et al.(2001) juga menyebutkan bahwapeer group support 
mampu menurunkan stres emosional dan sosial sehinggamampu mengelola penyakinya dan kestabilan glukosa darah bahkan menurunkankerentang normal.

Kedua hasil penelitian tersebut bertentangan dengan hasil penelitian ini.Diketahui bahwa hanya terdapat sebagian kecil yaitu 37,5\% yang mengalamipenurunan kadar glukosa darah. Pengontrolan kadar glukosa darah pada penderitaDM memang fluktuatif. Hal ini disebabkan banyak faktor yang mempengaruhipeningkatan glukosa darah pada penderita DM. Berbagai faktor yang dapatmempengaruhi kadar glukosa darah antara lain pola makan, olahraga danaktivitas, obat, penyakit, usia, stres dan alkohol (Tandra, 2008).

Menurut peneliti, ketidakstabilan glukosa darah pada responden kelompokperlakuan disebabkan oleh kurangnya kemampuan responden dalam mengontrolemosi. Emosi yang berlebihan serta dalam jangka panjang akan menyebabkanstres. Beberapa hormon yang dilepaskan selama stres berlangsung dapatmenghambat efek insulin yang dikeluarkan oleh sel $\beta$. Hal ini menyebabkan kadarglukosa darah tidak terkontrol meskipun telah menjalankan pilar pengelolaanpenyakit DM berupa diet, exercise, dan konsumsi obat (Misnadiarly, 2006). Halsenada ditunjukkan responden pada kelompok kontrol. Responden kelompokkontrol setelah intervensi terdapat sebagian kecil yaitu $1(12,5 \%)$ responden yangmengalami penurunan glukosa darah, yaitu responden dengan no. kode 8.Mengatur pola makan merupakan pilar utama pengendali glukosa darah(Misnadiarly, 2006). Responden tersebut telah mengatur pola makannya denganbaik sebelum ataupun sesudah intervensi dengan tingkat kepatuhan baik. Hal inimenyebabkan terkontrolnya glukosa darah pada responden tersebut.

\section{SIMPULAN DAN SARAN}

\section{Simpulan}

Simpulan pada penelitian ini sebagai berikut 1) peer group support dengan media informasi booklet tidak berpengaruhterhadap peningkatan kepatuhan dalam menjalankan diet pada penderitaDM di wilayah kerja Puskesmas
Surabayadimungkinkan karena responden masih leluasa mendapat informasi tentangdiet sehingga bisa mengatur dietnya; 2) peer group support dengan media informasi booklet berpengaruh terhadappeningkatan kepatuhan dalam menjalankan exercise pada penderita DM di wilayah kerja Puskesmas Kebonsari Surabaya dimungkinkankarena responden masih terbatas mendapatkan informasi tentang exercise; 3) peer group support dengan media informasi booklet berpengaruh terhadappeningkatan kepatuhan dalam menjalankan konsumsi obat pada penderitaDM di wilayah kerja Puskesmas Kebonsari Surabayadimungkinkan karena responden masih terbatas mendapatkan informasitentang konsumsi obat sehingga belum bisa mengatur konsumsi obatnya; 4) peer group support dengan media informasi booklet tidak berpengaruh padapeningkatan kepatuhan diet karena penderita mendapatkan informasitambahan dari pihak luar dan 5) peer group support berpengaruh padapeningkatan kepatuhan exercise dan konsumsi obat karena penderita tidakmendapatkan informasi tambahan dari pihak lain.

\section{Saran}

Peneliti menyarankan agar: 1) peer group support dijadikan wadah interaksi antar penderita DM tipe 2 dan salingmemberikan dukungan baik berupa informasi maupun emosional; 2) pelayanan Puskesmas ditingkatkan dengan cara memberikan pelatihankepada perawat/petugas kesehatan dalam upaya meningkatkan kepatuhanpengelolaan penyakit DM tipe 2 berupa diet, exercise, dankonsumsi obat dan cara memberikan kegiatan peer group support denganbenar karena melalui peer group support terbukti efektif dan efisien dalam memberikan informasi kesehatan; 3) petugas pelayanan kesehatan khususnya perawat dapat menggunakanintervensi peer group support sebagai salah satu intervensi pemberdayaandan peningkatan kemampuan pemecahan masalah pada penderita DM tipe 2 sehingga penderita dapat meningkatkan kepatuhan dalam mengelola penyakitnya; 4) hasil maksimal dapat dicapai bila observasi diet, exercise dan konsumsiobat dilakukan lebih lama dengan observasi dua arah dan instrument yang sudah baku 


\section{KEPUSTAKAAN}

Annisa, F 2009,Skripsi: Pengaruh Pemberian Jus Kacang Panjang (Vigna Sinensis L.) Terhadap Penurunan Kadar Glukosa Darah Pada PasienDiabetes Mellitus Tipe 2 Di Puskesmas Pacar Keling Surabaya,Fakultas Keperawatan Universitas Airlangga,Surabaya

Bandura, A 1997,Self Efficacy: The Exercise Of Control, Freeman, New York

Barnes, DE 2012,Program Olahraga Diabetes: Panduan untuk MengendalikanGlukosa Darah alih bahasa Aburiyati,PT. Citra Aji Parama,Yogyakarta

FKUI 2009,Penatalaksanaan Diabetes Mellitus Terpadu sebagai PanduanPenatalaksanaan Diabetes Mellitus bagi Dokter dan Edukator, Balai Penerbit FKUI,Jakarta

Friedman, MM 1998, Keperawatan Keluarga: Teori dan Praktek, EGC, Jakarta

Gail, EB, Robert, LB, Fredric, MW, Karen, F 2010, The Effects of a Web-Based Intervention on Psychosocial WellBeing Among Adults Aged 60 and Older With Diabetes: A Randomized Trial. Diabetes Educator, Vol. 36, No. 11, Hal. 446-456

Gitawati, DS 2007,Skripsi: Pengaruh Peer Group Support terhadap HargaDiri Manula,Fakultas Keperawatan Universitas Airlangga,Surabaya

Greco, P, Pendley, JS, McDonell, K, Reeves, G 2001, A Peer Group Intervention for Adolescents With Type 1 Diabetes and Their Best Friends, Journal of Pediatric Psychology, Vol.26, No.8, Hal.: 485-490

Heisler, M 2007, Overview of Peer Support Models to Improve Diabetes SelfManagement and Clinical Outcomes, Diabetes Spectrum, Vol. 20, No. 4, Hal.: 214-221

Heisler, M, Vijan, S, Makki, F, Piette, JD, 2010, Diabetes Control With Reciprocal Peer Support Versus Nurse Care Management A Randomized Trial, Annals of Internal Medicine, Vol.153,No.8,Hal.: 507-515
Ilkafah 2011,Thesis: Pengaruh Peer Group Support Terhadap Self Efficacy Kontol Gula Darah dan Self Care Activities pada Penderita Diabetes Mellitus Di Puskesmas Mantup Kabupaten Lamongan,Fakultas Keperawatan Universitas Airlangga, Surabaya

Ilyas, EI 2009, "Olahraga bagi Diabetes". Dalam Soegondo, S., Soewondo, P., Subekti, I. (ed), Penatalaksanaan Diabetes Mellitus Terpadu: PanduanPenatalaksanaan Diabetes Mellitus Bagi Dokter Dan Educator, Balai Penerbit FKUI,Jakarta

Misnadiarly 2006,Ulcer, Gangren, Infeksi Diabetes Mellitus: Mengenali GejalaMenanggulangi Mencegah Komplikasi, Pustaka Popular Obor, Jakarta

Niven, N 2005, Psikologi Kesehatan, Penerbit Erlangga, Jakarta

Norris, SL, Engelgau, MM, Narayan, KMV 2001, Effectiveness of SelfManagement Training in Type 2 Diabetes A systematic review of randomized controlled trials, Diabetes Care, Vol. 24, No. 3, Hal.: 561-587

Notoatmodjo, S., 2007. Promosi Kesehatan dan Ilmu Perilaku Cetakan Pertama, PT. Rineka Cipta, Jakarta

Nuryati 2010,Skripsi: Pengaruh Peer Group Support Terhadap PerubahanTingkat Pengetahuan Sikap dan Tindakan Keluarga dalam Merawat Penderita Skizofrenia,Fakultas Keperawatan Universitas Airlangga,Surabaya

Peplau, LA 2002,Social Psychology Edition 7, Prentice Inc., New Jersey

PERKENI, 2011. Konsensus Pengelolaan dan Pencegahan Diabetes Mellitus Tipe 2 Di Indonesia. Jakarta.

Randall, MC 2010, Support Group:What They Are and What They Do,Diakses 4 April 2012 dari http//www.genetikhealth

Smeltzer, SC \& Bare, CB 2002, Buku Ajar Keperawatan Medikal Bedah Brunner \& Suddarth Edisi 8 vol.2, alih bahasa H.Y. Kuncara, Andry Hartono, Monica Ester, Yasmin Asih, Penerbit EGC, Jakarta

Smet, B 1994,Psikologi Kesehatan,PT.Grasindo, Jakarta

Soegondo, S, Soewondo, P, \&Subekti, I (ed) 2009,Penatalaksanaan Diabetes 
Mellitus Terpadu: Panduan

Penatalaksanaan Diabetes Mellitus Bagi Dokter dan Educator, Balai Penerbit FKUI, Jakarta

Tandra, H 2008,Segala Sesuatu yang Harus Diketahui Tentang Diabetes, Gramedia Pustaka Utama, Jakarta
Tjokroprawiro, A 2011,Hidup Sehat dan Bahagia Bersama Diabetes: PanduanLengkap Pola Makan untuk Penderita Diabetes, PT. GramediaPustaka Utama, Jakarta 